\title{
Familial exudative vitreoretinopathy
}

INSERM

\section{Source}

INSERM. (1999). Orphanet: an online rare disease and orphan drug data base. Familial exudative vitreoretinopathy. ORPHA:891

Familial exudative vitreoretinopathy (FEVR) is a rare hereditary vitreoretinal disorder characterized by abnormal or incomplete vascularization of the peripheral retina leading to variable clinical manifestations ranging from no effects to minor anomalies, or even retinal detachment with blindness. 